\title{
Palaeoecological and palaeoenvironmental significance of some important spores and micro-algae in Quaternary deposits
}

\author{
TANG Ling $\mathrm{Yu}^{1}$, MAO LiMi $^{1 *}$, LÜ XinMiao $^{2}$, MA QingFeng $^{2,3}$, ZHOU ZhongZe $^{4}$, \\ YANG ChunLei ${ }^{4}$, KONG ZhaoChen ${ }^{5} \&$ BATTEN David $\mathbf{J}^{6}$ \\ ${ }^{1}$ State Key Laboratory of Palaeobiology and Stratigraphy, Nanjing Institute of Geology and Palaeontology, Chinese Academy of Sciences, \\ Nanjing 210008, China; \\ ${ }^{2}$ Key Laboratory of Tibetan Environment Changes and Land Surface Processes, Institute of Tibetan Plateau Research, Chinese Academy of \\ Sciences, Beijing 100085, China; \\ ${ }^{3}$ University of Chinese Academy of Sciences, Beijing 100049, China; \\ ${ }^{4}$ School of Resources and Environmental Engineering, Anhui University, Hefei 230039, China; \\ ${ }^{5}$ Institute of Botany, Chinese Academy of Sciences, Beijing 100093, China; \\ ${ }^{6}$ School of Earth, Atmospheric and Environmental Sciences, University of Manchester, Manchester M13 9PL, UK
}

Received August 3, 2012; accepted January 24, 2013; published online April 12, 2013

\begin{abstract}
Spores of ferns and allied plants, and micro-algae frequently occur in abundance in Quaternary deposits, but their palaeoenvironmental significance is seldom evaluated. This paper presents morphological descriptions of spores of Selaginella sinensis (Desv.) Spring, 1843 (Selaginellaceae) and Ceratopteris cf. thalictroides (L.) Brongniart, 1821 (Parkeriaceae) and the algae Pediastrum boryanum (Turpin) Meneghini, 1840, P. simplex Meyen, 1829, P. integrum Nägeli, 1849 (all Hydrodictyaceae), Spiniferites Mantell, 1850, emend. Sarjeant, 1970 (Spiniferitaceae) and Concentricystes Rossignal, 1962, emend. Jiabo, 1978 (systematic position unclear), and discusses their occurrence in mostly Quaternary sedimentary successions. All are closely associated with aquatic habitats. Extant Selaginella sinensis often colonizes fairly wet hillsides and gaps between rocks, and shady sides of ravines and slopes; it is also found within thickets of trees and shrubs (boscages) and in forests with calcareous soils. Ceratopteris thalictroides, Pediastrum and Concentricystes inhabit freshwater lakes and both natural and artificial wetlands, such as paddy fields and ditches. Spiniferites is a salt-water genus and usually associated with the marine realm. Fossil and subfossil representatives of all of these taxa can be useful proxies of biodiversity and, therefore, also important for determining environmental conditions during the Quaternary period.
\end{abstract}

pteridophyte spores, micro-algae, hydrophytes, lakes, wetlands, Quaternary deposits

Citation: Tang L Y, Mao L M, Lü X M, et al. Palaeoecological and palaeoenvironmental significance of some important spores and micro-algae in Quaternary deposits. Chin Sci Bull, 2013, 58: 3125-3139, doi: 10.1007/s11434-013-5747-9

Abundant pteridophyte spores and algal palynomorphs (micro-algae) occur frequently in Quaternary deposits owing to their wide distribution. Although ferns and allied plants may be found in habitats that vary considerably in temperature, amount of precipitation received and soil composition, they are usually most numerous and diverse in warm, shady, humid environments and, as a result, are commonly key elements of understorey herbs in forests. It has been

*Corresponding author (email: lmmao@nigpas.ac.cn) demonstrated on many occasions in the past that the distribution of spores of pteridophytes that are preserved in sediments and sedimentary rocks can indicate the palaeoecology of their parent plants. Most algae are aquatic. Many occur in fresh and brackish habitats, such as species of Pediastrum in freshwater lakes, as well as in salt water, such as Spiniferites offshore in the marine realm. In a recent palynological study on lake sediments from drill cores on the Tibetan plateau, we found Pediastrum in freshwater to slightly brackish sediments, species compositions altering 
according to locality and varying depositional conditions. In addition, species richness and abundance of this genus varies with depth of water and even in different cores from the same lake; thus, both can be indicative of past aquaticecosystem changes.

The significance of pteridophyte spores and micro-algae in palaeoclimatic and palaeoecological reconstructions of Quaternary sedimentary successions has been generally under-evaluated hitherto, despite their frequent occurrence in deposits of this age. The reasons for this are unclear, but may include identification problems or unrecognized types of, for example, meadow or marsh vegetation. By not taking into account their occurrence, palaeoenvironmental conclusions drawn mainly on the basis of the angiosperm pollen record may not be as accurate as they might have been had this information been taken into account. Since many studies of pre-Quaternary sediments have shown that some pteridophyte spores can be useful indicators of environmental changes through time, there is no reason why their occurrence in Quaternary successions should not prove equally useful.

For example, fossil spores of the extant species Selaginella sinensis have been recorded from the Zhoukoudian site of ape man in the Beijing area of China, indicating a warm climate. This determination is at variance with previous interpretations of cold, damp conditions because $S$. sinensis spores were incorrectly identified as Botrychium or Pteris. Kong et al. [1] corrected these mistakes and interpreted the occurrence of $S$. sinensis to indicate not only a warm but also a generally dry climate.

Our current palynological investigation of Holocene deposits at Anxin in northern China has revealed that Ceratopteris cf. thalictroides is richly represented. However, the modern distribution of this species is limited to the south of the Huaihe and Yangtze rivers in eastern China, which is a subtropical region. Hence, the subfossil record indicates that conditions at Anxin were warmer and more humid during the Holocene than they are now.

Zhu et al. [2] and Wang et al. [3-5] reported fossil and subfossil algae in eastern China during the 1970s and 1980s, and Mao et al. [6] recently evaluated the potential significance of abundant pteridophyte spore and micro-algal records from deltaic sediments of the Yangtze River recovered by drilling into early Holocene deposits at Fengxian in Shanghai. However, because of limited work on the ecology of many extant pteridophytes and micro-algae and the relationship between their occurrence and the deposition of their spores and other remains in sediments, palaeoecological and palaeoenvironmental determinations have been limited to a very few situations or have merely focused on arbitrarily selected species.

In this paper we present morphological descriptions and data on, and the palaeoecological significance of, fossil and subfossil remains of seven types of spores and micro-algae in China in a geological context (location, epoch and distribution) in order to refine Quaternary biological proxies and improve palaeoecological and palaeoenvironmental interpretation.

\section{Fossil and subfossil spores and micro-algae, and their morphological description}

We summarize below the fossil and subfossil records of spores of two pteridophyte species and remains of five types of micro-algae based on both published and our own, recently acquired data. The material reviewed and examined is from many parts of China, as shown in Table 1, which

Table 1 Data on fossil and subfossil spores of Selaginella sinensis and Ceratopteris, and of the algae Pediastrum (three species), Spiniferites and Concentricystes

\begin{tabular}{|c|c|c|c|}
\hline Fossil-subfossil & Location & $\begin{array}{c}{ }^{14} \mathrm{C} \text { date (cal ka BP) or } \\
\text { geological epoch }\end{array}$ & Reference \\
\hline \multirow{20}{*}{ Selaginella sinensis } & Fula'erji in Heilongjiang & late Cenozoic & [7] \\
\hline & Qian'an in Jilin & late Tertiary & [8] \\
\hline & Hohhot, Gu'aohan in Inner Mongolia & Holocene & [9] \\
\hline & Daqingshan in Inner Mongolia & $7.5-6.2$ & {$[10]$} \\
\hline & Xinglongwa in Inner Mongolia & $8.3-8.1$ & [11] \\
\hline & Chifeng in Inner Mongolia & $8.9-6.8$ & {$[11]$} \\
\hline & Qarhan Salt Lake, Tsaidam Basin in Qinghai & $33.0-28.7$ & {$[12]$} \\
\hline & Qinghai lake & Holocene & {$[13]$} \\
\hline & Zhoukoudian in Beijing & Pleistocene, Holocene & {$[1]$} \\
\hline & Fenzhuang in Beijing & Holocene & {$[14]$} \\
\hline & Beijing & late Tertiary-Holocene & {$[15]$} \\
\hline & West coast of Bohai Bay & Holocene & [16] \\
\hline & Dalianhuapao in Dalian & 1.8 & [17] \\
\hline & Baiyangdian in Hebei & Holocene & [18] \\
\hline & Anxin in Hebei & Pleistocene & This paper \\
\hline & Coast of Qingdao in Shangdong & Holocene & [19] \\
\hline & Linyi in Shandong & Holocene & \\
\hline & Mianyang in Sichuan & Holocene & \\
\hline & Xinghua in Jiangsu & Pleistocene & This paper \\
\hline & Lianyungang in Jiangsu & Holocene & \\
\hline
\end{tabular}


(Continued)

\begin{tabular}{|c|c|c|c|}
\hline Fossil-subfossil & Location & $\begin{array}{c}{ }^{14} \mathrm{C} \text { date (cal ka BP) or } \\
\text { geological epoch }\end{array}$ & Reference \\
\hline \multirow{33}{*}{$\begin{array}{l}\text { Ceratopteris cf. } \\
\text { thalictroides }\end{array}$} & Xinglongwa in Inner Mongolia & $7.47-6.90$ & [11] \\
\hline & Yanqin, Shunyi in Beijing & $8.1-5.7$ & {$[10]$} \\
\hline & Tangu, Jinghai, Beitang in Tianjin & $8.1-5.7$ & [10] \\
\hline & Anxin in Hebei & Pleistocene-Holocene & This paper \\
\hline & Huanghua in Hebei & Holocene & {$[10]$} \\
\hline & Baiyangdian in Hebei & $8.1-6.8$ & {$[18,20]$} \\
\hline & Mengcun in Hebei & $8.9-5.7$ & [10] \\
\hline & Shenxian, Jingxian, Renxian in Hebei & $8.9-3.3$ & {$[10]$} \\
\hline & Heilonghong, Cangzhou in Hebei & 8.9 & {$[10]$} \\
\hline & Hills of Jibei, Guanzhong Plain in Hebei & $8.3-5.7$ & [11] \\
\hline & Bohai Bay in Hebei & $8.9-5.7$ & {$[21]$} \\
\hline & Continental shelf of East China Sea, coast of Bohai in Hebei & late Tertiary & {$[22]$} \\
\hline & Zhengzhou in Henan & Holocene & This paper \\
\hline & Xinzheng Jiahu, Dazhengzhuang in Henan & $8.9-5.7$ & [10] \\
\hline & Peiligang in Henan & $8.9-8.1$ & [10] \\
\hline & Coast of Qingdao in Shandong & $8.9-5.7$ & {$[10]$} \\
\hline & Nansihu, Cuixian, Humin in Shandong & $8.9-5.7$ & [10] \\
\hline & Yellow River Delta & $8.3-5.7$ & [10] \\
\hline & Jiaozhou Bay in Shandong & Holocene & [23] \\
\hline & Rizhao in Shandong & $8.7-5.7$ & [10] \\
\hline & Wangyin in Yanzhou, Shandong & 5.7 & [10] \\
\hline & Linyi in Shandong & Holocene & This paper \\
\hline & Tancheng in Shandong & 5.9 & {$[10]$} \\
\hline & Congyang in Anhui & 8.9 & [24] \\
\hline & Lüsi in Jiangsu & Holocene & \\
\hline & Xinghua and Taizhou in Jiangsu & Pleistocene & This paper \\
\hline & Guangfulin, Chongming Island in Shanghai & Holocene & \\
\hline & Fengxian in Shanghai & Holocene & [6] \\
\hline & Hemudu, Yuyao, Linshan in Zhejiang & Holocene & This paper \\
\hline & Baohuashan, Nanjing in Jiangsu & 5.8 & [25] \\
\hline & Basin of southern Yellow Sea & Pleistocene, late Tertiary & [26] \\
\hline & Leizhou Pennisula in Guangdong & Pleistocene, late Tertiary & [27] \\
\hline & Continental shelf, northern South China Sea & late Tertiary & [28] \\
\hline \multirow{22}{*}{ Pediastrum spp. } & Fula'erji in Heilongjiang & late Cenozoic & [7] \\
\hline & Qian'an in Jilin & late Tertiary & {$[8]$} \\
\hline & Yinming River, Hunlunbuir in Inner Mongolia & 5.2 & [9] \\
\hline & Anxin in Hebei & Holocene & This paper \\
\hline & Duantouliang, Tengger Desert & Late Pleistocene & [29] \\
\hline & Shallow lake, Badanjilin Desert & Late Pleistocene & [29] \\
\hline & Qarhan Salt Lake, Qaidam Basin in Qinghai & $33.0-28.7$ & [12] \\
\hline & Eastern Qaidam Basin in Qinghai & $37.8-21.5$ & [30] \\
\hline & Hurleg Lake in Qinghai & $10.8-0.1$ & {$[31]$} \\
\hline & Nam Co in Tibet & $17.8-10.96$ & \multirow{2}{*}{ This paper } \\
\hline & Gongzhu Co in Tibet & Holocene & \\
\hline & Pumoyum Co in Tibet & $19.0-0.5$ & {$[32]$} \\
\hline & Ahung Co, Co Ngion in Tibet & $8.3-1.8 ; 6.3-1.8$ & [33] \\
\hline & La'ang Co in Tibet & Holocene & This paper \\
\hline & Ren Co in Tibet & $8.5-6.0$ & [34] \\
\hline & Hidden Lake in Tibet & $14.0-0.5$ & [33] \\
\hline & Zigetang Lake in Tibet & Holocene & [35] \\
\hline & Tanggulashan (Tglsh) Co in Tibet & $4.3-38$ & [33] \\
\hline & Yidun Glacial Lake in Sichuan & $11.0-0.5$ & {$[34]$} \\
\hline & Wulungu Lake in Xinjiang & $9.55-3.62$ & {$[36,37]$} \\
\hline & Bosten Lake in Xinjiang & $8.0-0.1$ & [38] \\
\hline & Kuming Lake in Beijing & $(1750-1960 \mathrm{AD})$ & [15] \\
\hline
\end{tabular}


(Continued)

\begin{tabular}{|c|c|c|c|}
\hline Fossil-subfossil & Location & $\begin{array}{c}{ }^{14} \mathrm{C} \text { date (cal ka BP) or } \\
\text { geological epoch }\end{array}$ & Reference \\
\hline \multirow{13}{*}{ Pediastrum spp. } & Qian'an in Hebei & $8.3-6.8$ & {$[20]$} \\
\hline & Anxin in Hebei & Pleistocene-Holocene & This paper \\
\hline & Peat layer on continental shelf of East China Sea, Yellow Sea & Late Pleistocene & [39] \\
\hline & Guangfulin, Chongming Island in Shanghai & Holocene & \multirow{2}{*}{ This paper } \\
\hline & Taizhou, Lüsi, Xinhua in Jiangsu & Pleistocene, Holocene & \\
\hline & Fengxian in Shanghai & Holocene & [6] \\
\hline & Yangchenghu in Jiangsu & Late Pleistocene & [39] \\
\hline & Yangtze River Delta & Recent & [40] \\
\hline & Xihu, Ningbo in Zhejiang & Late Pleistocene, Holocene & [40] \\
\hline & Hemudu, Yuyao, Linshan in Zhejiang & Holocene & This paper \\
\hline & Dianchi in Yunnan & Holocene & [41] \\
\hline & Shuangchi Maar Lake, Hainan Island & $1.7-0.7$ & [42] \\
\hline & Huguangyan Maar Lake in Guangdong & 4.5 & [43] \\
\hline \multirow{11}{*}{ Spiniferites } & Basin of South Yellow Sea & Pleistocene, late Tertiary & {$[44,26]$} \\
\hline & Coast of Bohai, Longjin Basin on the continent shelf, East China Sea & late Tertiary & {$[45,46]$} \\
\hline & Continental shelf, East China Sea & Cenozoic & {$[47,48]$} \\
\hline & Dongying in Shangdong & Late Pleistocene & [49] \\
\hline & Continental shelf, north South China Sea & late Tertiary & {$[28]$} \\
\hline & Lianyungang, Lüsi in Jiangsu & Holocene & \multirow{2}{*}{ This paper } \\
\hline & Taizhou, Xinghua in Jiangsu & Late Pleistocene & \\
\hline & Fengxian in Shanghai & Holocene & [6] \\
\hline & Baiyangdian in Hebei & Holocene & \multirow{3}{*}{ This paper } \\
\hline & Guangfulin, Chongming Island in Shanghai & Holocene & \\
\hline & Hemudu, Yuyao, Linshan in Zhejiang & Holocene & \\
\hline \multirow{29}{*}{ Concentricystes } & Mudanjiang in Helongjiang & Holocene & This paper \\
\hline & Liaoning, Shandong and Bohai & Tertiary & [45] \\
\hline & Anxin in Hebei & Pleistocene & \\
\hline & Linyi in Shandong & Holocene & This paper \\
\hline & Hefei in Anhui & Holocene & {$[25]$} \\
\hline & Lianyungang, Lüsi in Jiangsu & Holocene & \multirow{2}{*}{ This paper } \\
\hline & Taizhou, Xinghua in Jiangsu & Late Pleistocene & \\
\hline & Nantong in Jiangsu & Pleistocene & {$[51]$} \\
\hline & Tailake in Jiangsu & Holocene & [40] \\
\hline & Ducunin Jiangsu & Holocene & {$[52]$} \\
\hline & Yangtze River Delta & Modern sediment & {$[40]$} \\
\hline & Jinshan, Fengxian in Shanghai & Holocene & {$[3,6]$} \\
\hline & Hemudu, Yuyao, Linshan in Zhejiang & Holocene & \multirow{3}{*}{ This paper } \\
\hline & Baiyangdian in Hebei & Holocene & \\
\hline & Chongqing & Holocene & \\
\hline & Hanzhou Bay in Zhejiang & Pleistocene, Holocene & {$[5]$} \\
\hline & Coasts of Yellow Sea and East China Sea & Late Pleistocene & {$[53,39]$} \\
\hline & Ningbo in Zhejiang & Holocene & {$[53]$} \\
\hline & Xishanxiyaohu, Lushan in Jiangxi & Holocene & {$[54]$} \\
\hline & Nanyang in Henan & Holocene & \multirow{2}{*}{ This paper } \\
\hline & Mianyang in Sichuan, Chongqing & Holocene & \\
\hline & Jinjiang in Fujian & Holocene & [5] \\
\hline & Dianchi in Yunnan & Modern sediment & {$[41]$} \\
\hline & Foshan in Guangdong & Holocene & This paper \\
\hline & Beibu Gulf in Guangxi & Pleistocene & {$[28]$} \\
\hline & Hong Kong & Late Pleistocene & {$[55]$} \\
\hline & Houhai, Shenzhen in Guangdong & Late Pleistocene & {$[56]$} \\
\hline & Sunda Shelf, South China Sea & 16.5 & {$[57]$} \\
\hline & Jilin & Holocene & [58] \\
\hline
\end{tabular}


provides information on locality, age, and source of data.

\subsection{Selaginella sinensis (Desv.) Spring, 1843}

In China, spores of Selaginella have been reported from late Cretaceous deposits in the Beijing area, but the earliest records of the products of Selaginella sinensis date back to the late Tertiary-Quaternary [14] in the form of specimens from Pliocene sandstone at Qian' an in Jilin and the Middle Pleistocene at Fula'erji in Heilongjiang [7, 8]. They have been recorded frequently from sediments of Pleistocene and/or Holocene age at Anxin in Hebei, Linyi in Shandong, Xinhua and Lianyungang in Jiangsu, and Mianyang in Sichuan (Table 1) during our recent palynological investigations (Figure 1).

Spores of Selaginella sinensis recovered during our study of Pleistocene and Holocene deposits show morphological consistency. They are rounded triangular to sub-circular in polar view, oblong in equatorial view, and ca. 33.3-41.1 $\mu \mathrm{m}$ in maximum diameter. A somewhat meandering trilete suture extends almost to the equator. The exine is thin and sculptured with verrucae. The irregular trilete mark, which lacks a margo, and comparatively large verrucae distinguish the spores of this species from those of Pteris and Botrychium (e.g. Botrychium lunaria (L.) Sw.), which are otherwise similar [58].

Selaginella sinensis is a perennial lycopsid and endemic to China. Its habitat is often fairly wet hillsides and gaps between rocks, shady sides of ravines and slopes, and within thickets of trees and shrubs (boscages) and forests with calcareous soils [59]. The genus Selaginella is widely distributed throughout the world, but in China it is mainly associated with temperate forests, forest-steppe and steppe areas to the north of the Yangtze River.

\subsection{Ceratopteris cf. thalictroides (L.) Brongniart, 1821}

In our study, spores of Ceratopteris cf. thalictroides have been found in Holocene deposits at Hemudu, Yuyao and

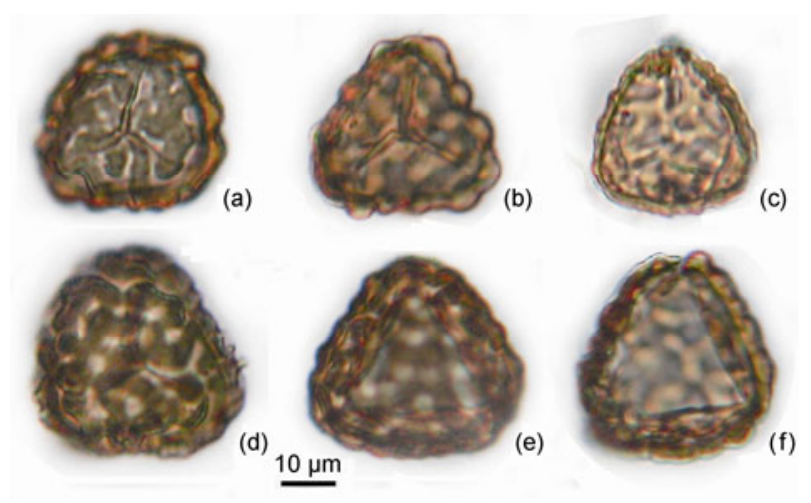

Figure 1 Fossil-subfossil spores of Selaginella sinensis (Desv.) Spring, 1843. (a)-(c) Pleistocene, Anxin in Hebei; (d)-(f) Holocene, Linyi in Shandong.
Linshan in Zhejiang, Guangfulin, Fengxian and Chongming Island in Shanghai, and Linyi in Shandong, and in Pleistocene and Holocene deposits at Anxin in Hebei, and Taizhou and Lüsi in Jiangsu (Table 1). Fossil-subfossil spores of Ceratopteris cf. thalictroides are also well documented from some other localities (e.g. Kong et al. [10,11]; see Table 1). They are very similar to the spores of extant $C$. thalictroides in being large (ca. 95-162.5 $\mu \mathrm{m}$ in maximum diameter), trilete and rounded triangular to sub-circular in polar view with a strongly convex distal surface. The laesurae of the trilete mark extend to approximately two-thirds of the radius of the spore. The exine is ca. $4.8 \mu \mathrm{m}$ thick and consists of two-layers; the outer layer is the thicker of the two and distinctly murornate. There are up to 6-7 muri on the distal surface arranged approximately parallel to the sides of the spore, but no more than 3-4 on each side of the trilete suture on the proximal face (Figure 2).

Fossil spores of Ceratopteris cf. thalictroides that have been recorded from late Tertiary deposits have commonly been referred to Magnastriatites and also sometimes to $\mathrm{Ci}$ catricosisporites, species of which are often especially numerous in early Cretaceous deposits in many parts of the world, but which also occur in younger Cretaceous and Tertiary strata [15,60-62]. These two genera are generally easy to distinguish and have different familial origins, with $\mathrm{Ci}$ catricosisporites representing the families Schizaeaceae and Pteridaceae and Magnastriatites referable to the Parkeriaceae. The latter genus was erected by Germeraad et al. [63] from mid Tertiary deposits in Colombia and has been found in early Oligocene-Pliocene strata there and in China, Nigeria, Indonesia and India. In China, the earliest fossil records of spores of Ceratopteris cf. thalictroides have been attributed to species of Magnastriatites in late Tertiary sediments in many regions [22,26,28,44,45,64], such as $M$. howardii Germeraad, Hopping and Muller in the middle part of the Longjing Formation in the continental-shelf basin of the East China Sea, M. granulastriatus Li and $M$. minutus Li from the Longjing through to the Yuquan formations of later Tertiary age [47] and M. leizhouensis
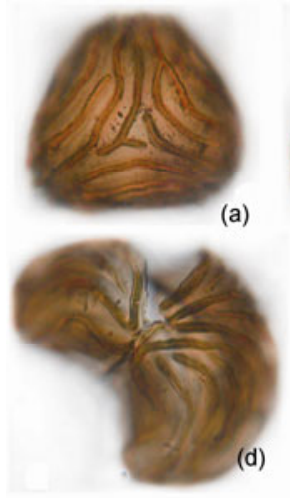

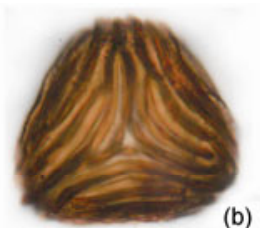

(b)

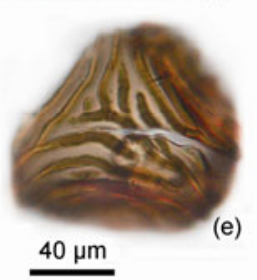

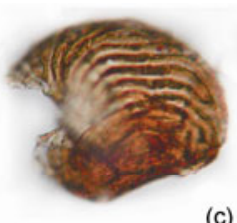

(c)

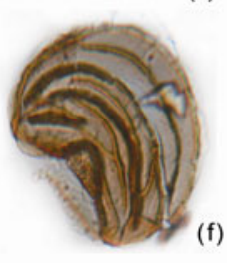

Figure 2 Fossil-subfossil spores of Ceratopteris cf. thalictroides (L.) Brongniart, 1821. (a)-(c) Pleistocene, Anxin in Hebei; (d)-(f) Holocene, Linyi in Shandong. 
Zhang in the late Miocene Weizhou Formation on the continental shelf of the northern South China Sea.

Both Ceratopteris cf. thalictroides and Magnastriatites are, therefore, classified in the pteridophyte family Parkeriaceae. Modern Ceratopteris thalictroides is an aquatic fern that is commonly found in ponds, paddy fields and ditches. In China it is widely distributed in Guangdong, Taiwan, Fujian, Jiangsu, Zhejiang, Anhui, Hubei, Sichuan, Guangxi and Yunan [65]. It also occurs in tropical and subtropical regions of Africa, Europe and other parts of Asia.

\subsection{Pediastrum boryanum (Turpin) Meneghini, 1840}

The earliest fossil record of Pediastrum boryanum is from the Cretaceous in Europe [66,67]. The oldest variety of this species to have been reported from China is $P$. boryanum var. undulatum Wille, 1879 from the Shahejie Formation in the Bohai area, which was dated as early Eocene-late Oligocene [46]. Pediastrum boryanum has also been recorded from Early Pleistocene sediments at Fula'erji in Heilongjiang [7]. Our records of this species come from Holocene sediments at Yuyao, Hemudu and Linshan in Zhejiang, Guangfulin, Fengxian and Chongming Island in Shanghai, and Pleistocene deposits at Taizhou and Lüsi in Jiangsu, and Anxin in Hebei (Table 1).

The coenobia of $P$. boryanum are disc-shaped oval or circular in outline, usually with 16-64 cells but sometimes comprising as many as 256 . The cells are irregular, 5-6sided polygons that are closely arranged, typically in $2-4$ concentric circles. Marginal cells have two lobes that are ca. $2-10 \mu \mathrm{m}$ in length. These are in the plane of the coenobium and separated from each other by U- or V-shaped invaginations. They become narrower outwards and have pointed tips. The cell wall is regularly granular. The coenobia and cells are usually ca. $50-160 \mu \mathrm{m}$ and ca. $10-30 \mu \mathrm{m}$ in maximum diameter, respectively (Figure 3 ).

\subsection{Pediastrum simplex Meyen, 1829}

Pediastrum simplex has been found in Holocene sediments

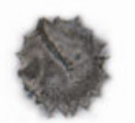

(a)

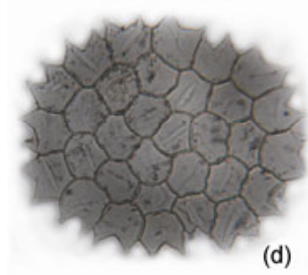

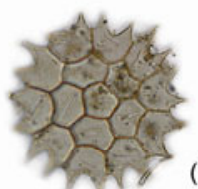

(b)
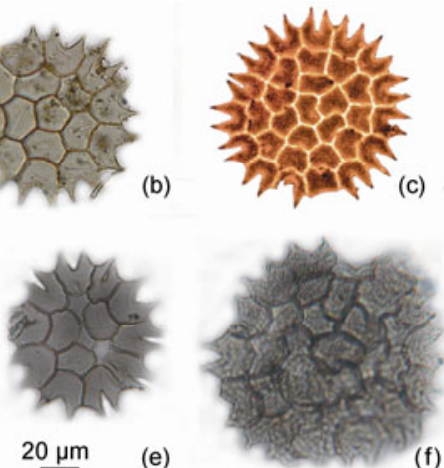

(e)

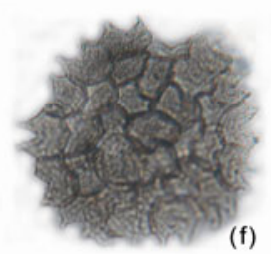

Figure 3 Fossil-subfossil Pediastrum boryanum (Turpin) Meneghini, 1840. (a) Pleistocene-Holocene, Anxin in Hebei; (b), (d), (e) PleistoceneHolocene, Nam Co in Tibet; (c) Holocene, Ahung Co in Tibet; (f) Holocene, Gongzhu Co in Tibet. at Lüsi in Jiangsu, and Yuyao, Hemudu and Linshan in Zhejiang, Guangfulin, Fengxian and Chongming Island in Shanghai; in Pleistocene sediments at Taizhou and Lüsi in Jiangsu and Anxin in Hebei; and in Pleistocene-Holocene deposits in Ahung Co, Tanggula Shan (Tglsh) Co, La'ang Co, Gongzhu Co and Nam Co in Tibet, and Yidun Glacial Lake in Sichuan (Table 1).

The coenobia of the specimens examined consist of 18-56 cells that are commonly partly separated by intercellular spaces. The inner cells are irregular, 5-6-sided polygons. The marginal cells have one narrowing lobe (Figure 4). In other respects, the morphology of this species is closely comparable to that of $P$. boryanum.

\subsection{Pediastrum integrum Nägeli, 1849}

Specimens of Pediastrum integrum were collected from Pleistocene-Holocene deposits in Nam Co and La'ang Co, Tibet (Table 1). The coenobia of those examined comprise 32-64 cells that, as for $P$. boryanum, are all connected, i.e. there are no intercellular spaces. The inner cells are irregular, 5-6-sided polygons. The marginal cells extend into two short lobes that are separated by only a shallow indentation. The cell wall is regularly granular. The dimensions of the cells are ca. $12-18 \mu \mathrm{m}$ and the maximum diameter of the coenobium is $120 \mu \mathrm{m}$ (Figure 5).

Other species of fossil Pediastrum have also been found in Chinese sediments. For example, in addition to $P$. boryanum and $P$. simplex, $P$. duplex Meyen has been recovered from Holocene sediments of Shuangchi Maar Lake on Hainan Island [68]. Zhang et al. [39] found specimens of $P$. simplex, $P$. duplex, $P$. boryanum, $P$. kawraiskyi Schmidle, $P$. biradiatum Meyen, $P$. integrum, $P$. mulicum Kuetz, $P$. clathratum (Schröder) Lemmermann and $P$. araneosum

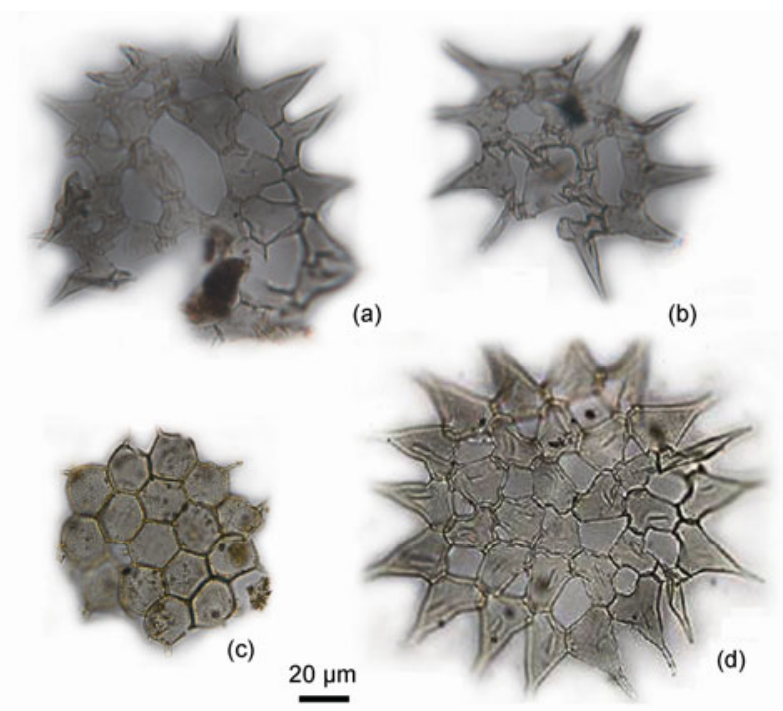

Figure 4 Fossil-subfossil Pediastrum simplex Meyen, 1829. (a) Holocene, Anxin in Hebei; (b) Holocene, Lüsi in Jiangsu; (c) Pleistocene-Holocene, Nam Co in Tibet; (d) Holocene, Fengxian in Shanghai. 


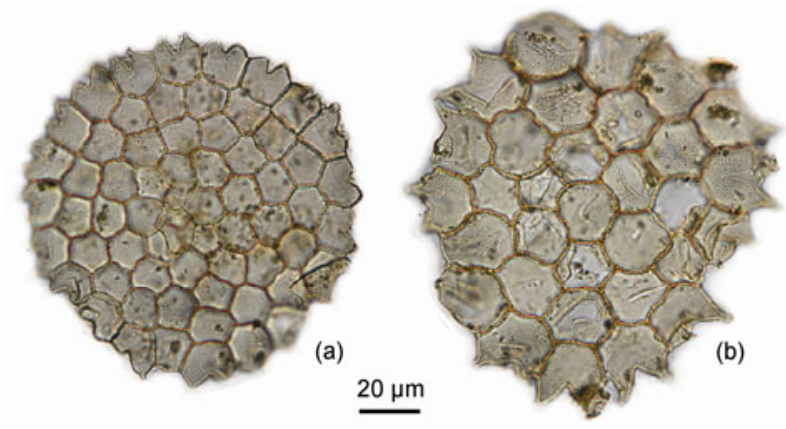

Figure 5 P. integrum Nägeli, 1849. (a), (b) Pleistocene-Holocene, Nam Co in Tibet.

(Racib.) Smith in drill core No.7 on the continental shelf of the South China Sea. Further afield, among other records of Pediastrum, Zamaloa and Tell [69] reported several species of different ages from South America: the oldest, $P$. boryanum var. boryanum, was recorded from late Cretaceous deposits of Rio Guaco, Venezuela; P. tetras (Ehrenberg) Ralfs from early Eocene deposits of Cerro La Huitrera, Argentina; and $P$. boryanum var. brevicorne Braun, $P$. boryanum var. longicorne Reinsch, $P$. duplex, P. integrum, $P$. kawraiskyi, $P$. leonensis Tell and Zamaloa, $P$. mustersii Tell and Mataloni and $P$. simplex from Miocene sediments of Monte Leon, Argentina.

\subsection{Spiniferites Mantell, 1850, emend. Sarjeant, 1970}

Fossil-subfossil micro-algae referred to Spiniferites were not identified to species in this study. The genus is known from the Cretaceous Period onwards in many parts of the world, e.g. [70], almost all representatives clearly indicating a marine environment. In China, they have been recovered from Holocene and/or Pleistocene sediments at Hemudu, Linshan and Yuyao in Zhejiang, Guangfulin, Fengxian and Chongming Island in Shanghai, and Lüsi, Taizhou, Lianyungang and Xinghua in Jiangsu, and are also well documented elsewhere (e.g. Zhu, 2004 [49]; Table 1).

Spiniferites is a spiniferate, chorate cyst with both sutural and gonal processes that delineate a paratabulation which reflects the tabulation of the living dinoflagellate. Many of the processes have broad bases and bifid or trifid terminations. The archeopyle is precingular. The dimensions of the cyst excluding the processes of the specimens examined are generally in the region of 30-40 $\mu \mathrm{m}$ (Figure 6).

Before the mid 1960s, spinose micro-algae of the same morphology were identified as Hystrochosphaera, but the research of Evitt [66], Rossignol [71] and others proved that these supposed fossil dinoflagellates were cysts and not the remains of motile thecae; hence, micro-algae with demonstrably dinoflagellate characters that had been described as "hystrichospheres" were considered to be dinoflagellate cysts and those lacking such characters were termed 'acritarchs'. For most of the time since then Hystrochosphaera has been regarded as a synonym of Spiniferites.

Around ten species of Spiniferites have been reported from the lower part of the Longjin Basin on the continental shelf of the East China Sea. Frequently occurring in Early Pleistocene deposits, they include S. bentorii (Rossignol) Wall and Dale, S. cf. bulloides (Deflandre and Cookson) Sarjeant, S. cingulatus var. spinatus Song, S. cf. hyperacanthus (Deflandre and Cookson) Cookson and Eisenack,
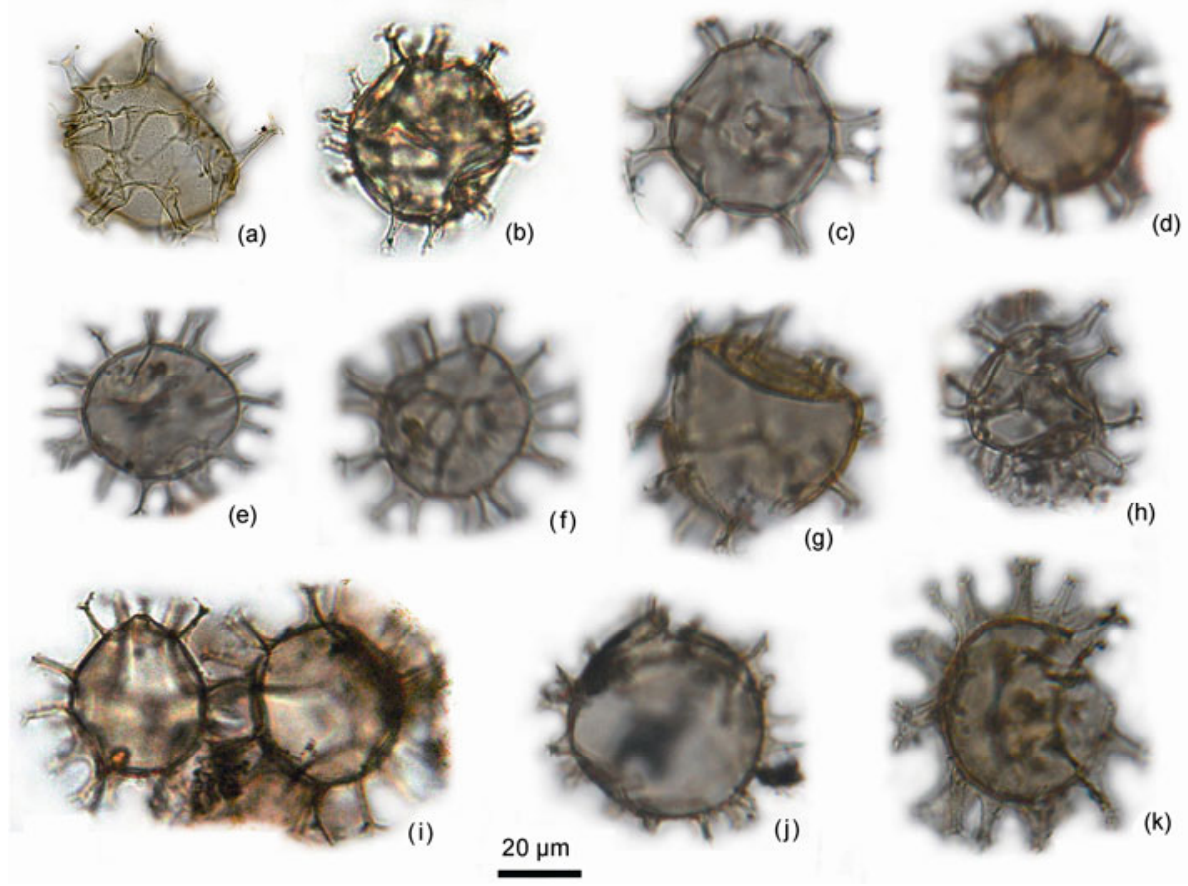

Figure 6 Fossil-subfossil Spiniferites. (a) Holocene, Fengxian in Shanghai; (b), (i) Pleistocene, Lianyungang in Jiangsu; (c), (g) Holocene, Guangfulin in Shanghai; (d)-(f), (j) Holocene, Lüsi in Jiangsu; (h), (k) Holocene, Hemudu in Zhejiang. 
S. membranaceus (Rossignol) Sarjeant, S. nodosus (Wall) Sarjeant and S. ramosus (Ehrenberg) Mantell, the identifications being based on general morphology and size, and the dimensions and morphology of the processes [44-47]. Yu [48] and Zhu [49] reported S. bentorii subsp. truncatus (Rossignol) Lentin and Williams, 1973, from early Eocene deposits in the upper Oujiang and lower Wenzhou formations in the continental-shelf basin of the East China Sea. Spiniferites bentorii has also been reported from the Eocene-early Oligocene Shahejie Formation on the Bohai coast: these are among the earliest fossil records of Chinese Spiniferites.

\subsection{Concentricystes Rossignal, 1962, emend. Jiabo, 1978}

The body of fossil-subfossil Concentricystes is subcircular or oval in polar view and may separate into two parts along the equator. Both parts are sculptured with narrow muri, most of which are orientated parallel to the equator so that they appear as essentially concentric rings, but at varying distances towards the poles they have a more broken appearance, reminiscent of a finger print (Figure 7). A thin outer membrane may also be present.

Concentricystes is of unclear systematic position. Wolff first recorded it from Pliocene lignite in Germany as Sporites [72]. It was described as Sporites circulus by Downie et al. [73] but later renamed by Rossignol [74] as Concentricystes rubinus. Rossignol treated Concentricystes as a freshwater alga and found abundant representatives in the bed of Wadi Kutin in Israel and in Quaternary alluvial deposits in North America and Australia [71]. Spores of Trachelomonas onulifera (Fritsch and Rich) Huberpestalozyi and T. stokesiana Palmer of the flagellate aquatic-algal

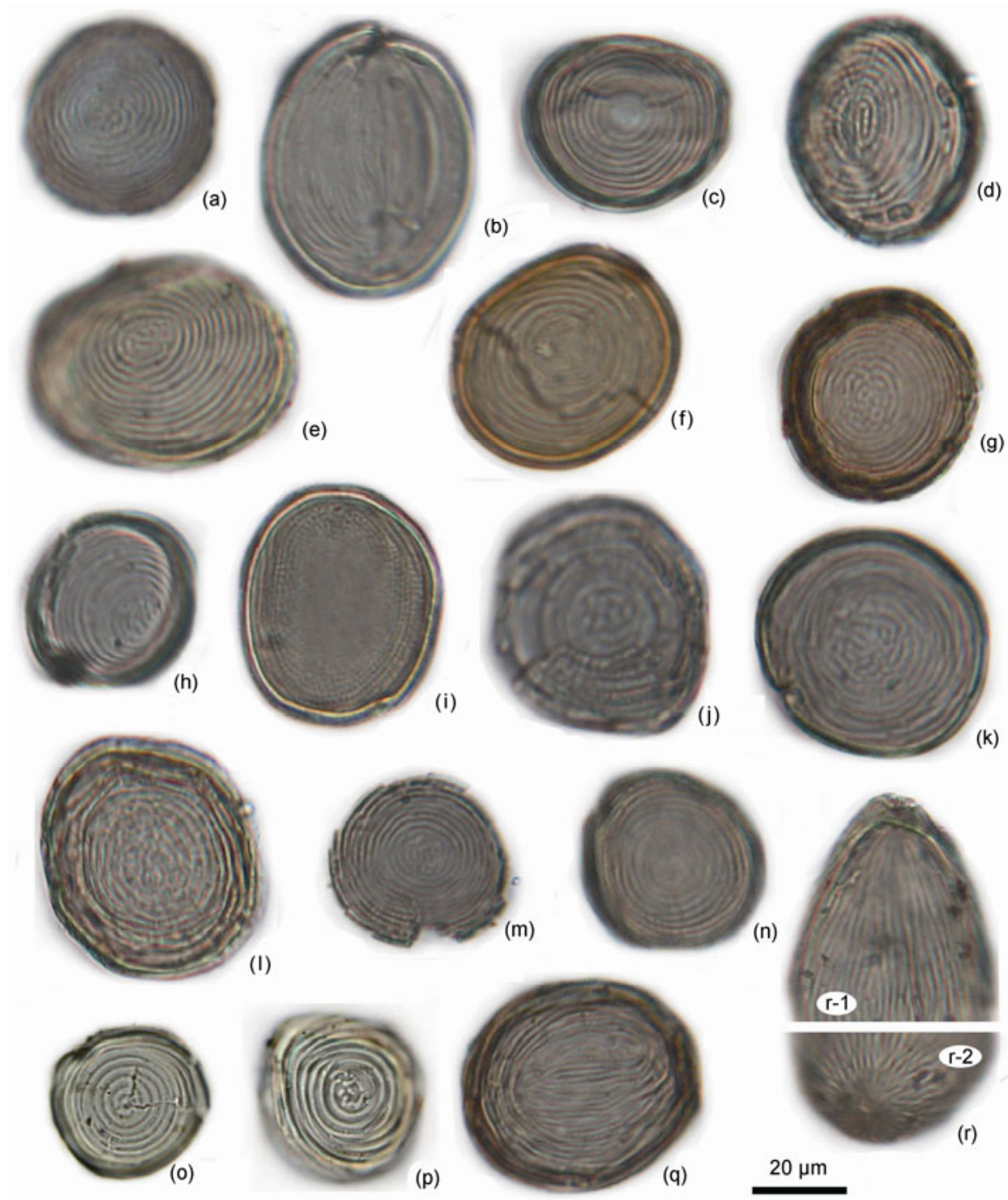

Figure 7 Fossil-subfossil Concentricystes Rossignal 1962, emend. Jiabo, 1978. (a)-(c) Pleistocene-Holocene, Anxin in Hebei; (d), (k), (1) PleistoceneHolocene, Lianyungang in Jiangsu; (e) Pleistocene-Holocene, Taizhou in Jiangsu; (f) Holocene, Foshan in Guangdong; (g), (m), (q) Holocene, Nanyang in Henan; (h), (i) Holocene, Hemudu in Zhejiang; (j) Holocene, Linyi in Shandong; (n) Holocene, Lüsi in Jiangsu; (o), (p) Holocene, Fengxian in Shanghai; (r) Holocene in Chongqing ((r-1), (r-2) different views). 
phylum Euglenophyta have an annular ornamentation similar to that of Concentricystes [46], but a systematic relationship between these taxa is unproven. Wu et al. [56] reported similar specimens from upper-Mid Pleistocene peat at Houhai, Shenzhen in Guangdong and identified them as Trachelomonas sp. Also similar are the specimens identified as Pseudoschizaea sp. by Medanic [75]. These were reported from coastal peat and lagoonal sediments in Rio Grande, Brazil.

Species of Concentricystes have been based on the presence or absence of a thin outer membrane and the structure of the ornament. In China, they include Concentricystes membranaceus Jiabo and C. panshanensis Jiabo [45,47], the former from late Tertiary deposits in Liaoning, Shandong and Bohai [45], and the latter from early Tertiary beds in the southern suburbs of Tianjin and the Dongying Formation in Shandong, and from the Minghuazhen Formation of late Tertiary age in Bohai [47].

Concentricystes occurs frequently in Quaternary lacustrine deposits, e.g. in Pleistocene lake muds at Yuanrangshanxia village, Dongyong, Dapu and Qingshuidao in Hong Kong [55]; Late Pleistocene peat at Houhai, Shenzhen in Guangdong [56]; Pleistocene-Holocene lacustrine sediments at Duncuo in Jiangsu [52]; Holocene sediments in the Mudanjiang area of Heilongjiang; Early Pleistocene deposits in Jilin [58]; and Holocene peat in Haidian, Beijing [76], but it has rarely been found in northwestern China and Tibet. Fossil-subfossil records in our study are from Pleistocene and Holocene deposits on the delta of the Yangtze River and Lianyungang and Lüsi in Jiangsu; the Pleistocene of Taizhou and Xinghua in Jiangsu; the Holocene of Chongming Island in Shanghai; and the Pleistocene and Holocene of Anxin in Hebei (Table 1).

\section{Results and discussion}

\subsection{Selaginella sinensis indicating an understory com- ponent of forests in a warm, humid climate}

In addition to the records of Selaginella sinensis from the Mid Pleistocene site of Beijing ape man at Zhoukoudian [1] and other Tertiary-Quaternary localities mentioned above, this species has also been found at the Palaeolithic site of Zhaowudameng Aohanqi in the Inner Mongolia Autonomous Region [9], and in the Pleistocene of Qarhan Salt Lake in the Qaidam Basin [12] and the Holocene of the Qingdao coast [38]. However, as noted in the introduction, the occurrence of spores of this species (along with the other taxa we discuss) and, hence, their stratigraphic and palaeoenvironmental significance, are often ignored in Quaternary pollen analyses. We attempt to remedy this situation here.

According to the Flora of China [65], the northernmost occurrence of Selaginella sinensis today is in the Daxing' an Mountain range $\left(50.24^{\circ} \mathrm{N}, 124^{\circ} \mathrm{E}\right)$ and the southernmost is in the Wudang Mountains $\left(31.6^{\circ} \mathrm{N}, 113.8^{\circ} \mathrm{E}\right)$. This area of distribution has a mean annual temperature range of $-2-15.6^{\circ} \mathrm{C}$ and $20.1-28^{\circ} \mathrm{C}$, with an annual precipitation that ranges from ca. 473 to $988 \mathrm{~mm}$. Hence, $S$. sinensis prefers a humid habitat and moderately high temperatures [59]. The westernmost occurrence of fossil-subfossil spores of $S$. sinensis is in the Qaidam Basin in Qinghai, the northernmost in Liaoning, the easternmost in Dalian and the southeasternmost in Ganyu. Thus, Pleistocene-Holocene spores of this species in Qinghai Lake and the Qaidam Basin $\left(36^{\circ} 40^{\prime}-37^{\circ} 10^{\prime} \mathrm{N}, 94^{\circ} 10^{\prime}-95^{\circ} 10^{\prime} \mathrm{E}\right)$ indicate that the plant was distributed more widely in the past that it is today, namely $2^{\circ}$ further north and $10^{\circ}$ further west. This implies that the climate was significantly warmer and more humid then [59].

Spores of Selaginella sinensis account for $80.2 \%$ of the palynological assemblage from the Mid Pleistocene deposits of Zhoukoudian, indicating warm interglacial conditions [58]. Abundant pteridophyte spores have been reported in the Dalianhua profile at Dalian [17], with those of S. sinensis comprising an extremely high percentage (90\%), indicating that the climate was warm and wet at around $1.7 \mathrm{cal}$. $\mathrm{Ka} \mathrm{BP}$. We have found abundant spores of this species in Pleistocene and Holocene lacustrine, wetland and tidal-flat deposits at Anxin in Hebei, Linyi in Shandong, and Xinghua and Lianyungang in Jiangsu. Hence, abundant spores of $S$. sinensis in sediments may be strongly associated with forest or forest-steppe vegetation, and linked mostly to warm, wet conditions.

\subsection{Ceratopteris cf. thalictroides indicating a warm to hot, humid climate and lacustrine and fluvial sedimen- tary environments}

During the late 1970s and early 1980s Ceratopteris cf. thalictroides was recorded (as Magnastriatites) from early Tertiary deposits of the Bohai Coast [46], the continental-shelf basin in the East China Sea [47] and the South Yellow Sea Basin [28], and from Pleistocene deposits on the Leizhou Peninsula [27].

Ceratopteris probably originated during the Late Eocene in tropical Asia and spread to other tropical regions during the Oligocene and also northwards later. Spores attributable to the genus have been recorded from deposits ranging in age from Oligocene to Quaternary in tropical regions [47], including the Caribbean, Nigeria and coastal Bay of Bengal. They have also been reported to occur frequently in sediments of late Tertiary-Quaternary age, but less commonly in early Tertiary deposits of the Bohai coast and Yangtze River Basin of eastern China.

As a monotype genus of Parkeriaceae, in common with the occurrence of the fossil-subfossil spores attributed to it, Ceratopteris is widely distributed in tropical and subtropical zones of the world. There are two species in China, namely Ceratopteris thalictroides and C. pteridodes (Hook) Hieron. 
These are mainly found in the southern Yangtze River area, growing in ponds, marshes, paddy fields and ditches, often floating on the water. Warm, still water is obviously a suitable habitat. The northernmost occurrence of Ceratopteris in China today has been recorded from Nansi Lake in Shangdong $\left(34.5^{\circ} \mathrm{N}\right)$ according to biogeographic data on the genus [65]. Southernmost occurrences are in Yunnan and Hainan Island. However, palynological studies have shown that mid Holocene sites (ca. 8.9-5.9 cal ka BP) 1-6 degrees of latitude further north than the current distribution of the genus have yielded spores attributable to $C$. cf. thalictroides, the northernmost occurrences being in Yanqing $\left(40.5^{\circ} \mathrm{N}\right)$ and Shunyi $\left(40.1^{\circ} \mathrm{N}\right)$ in Beijing [10]. If temperature changes by $0.6^{\circ} \mathrm{C}$ per degree of latitude, as is generally accepted, it can be inferred that the annual mean temperature at these sites during the mid Holocene would have been $0.6-3.6^{\circ} \mathrm{C}$ higher than today, i.e. the climate of Hebei and Shandong was much warmer and wetter then than it is now. We have recently found spores of $C$. cf. thalictroides, pollen of $\mathrm{Cy}$ peraceae and Typha, and freshwater algae indicative of a warmer and wetter climate than at present in PleistoceneHolocene sediments in the Anxin and Baiyangdian areas. Another example is from the ruins of Wangyin inYanzhou, Shandong: abundant spores of $C$. cf. thalictroides have been logged, indicating that the mean annual temperature of the Huanghuai area in central eastern China (i.e. between the Yellow and Huai rivers) was $2^{\circ} \mathrm{C}$ higher than at present and that large areas of lakes and bogs probably developed there [11]. The extremely rich assemblages of $C$. cf. thalictroides in deposits dated to $6.8 \mathrm{cal} \mathrm{ka} \mathrm{BP}$ at Baiyangdian in Hebei [18] and to $5.9 \mathrm{cal} \mathrm{ka} \mathrm{BP}$ at Tancheng in Shandong, indicate that the mean January temperature of the Haihe area at 5.9 cal ka BP was $5 \pm 2^{\circ} \mathrm{C}$, which is $9 \pm 2^{\circ} \mathrm{C}$ higher than at present in Baoding, Hebei, and the mean January temperature at Tancheng in Shandong was $3.5 \pm 1^{\circ} \mathrm{C}$ higher than today $[24,25]$.

The occurrence of $C$. cf. thalictroides in early to mid Holocene (about 8.9-5.9 cal ka BP) deposits of the Haihe River Basin, the Yellow River Delta and the coast of Bohai Bay, as well as in the southern Yangtze River area where Ceratopteris still exists, has palaeoenvironmental significance [10]. The pollen assemblages are dominated by Quercus, Ulmus and Betula; however, several tropical and subtropical pollen types have been recovered from sediments dated at 8.3 to $5.7 \mathrm{cal} \mathrm{ka} \mathrm{BP}$ in Haihe, the Yellow River Delta, Beijing, Tianjin, eastern Hebei, the Guanzhong plain and the northern Hebei hills, including Fagus, Liquidambar, Carya and Ceratopteris [16], probably indicating that the climate was fairly humid. Some pollen of trees, shrubs and other plants that inhabit the subtropics, such as Quercus (including evergreen type), Symplocus, Myrica, Liquidambar, Ilex, Fagus, Ceratopteris and Pteris, are indicative of vegetation that is transitional between temperate broadleaf forests and subtropical evergreen and deciduous broadleaf forests, linking it to a much warmer and wetter climate than at present $[21,23]$.

Numbers of Ceratopteris plants may increase abruptly when the water temperature and quality are suitable. Such increases have a significant impact on the ecology and hydrologic conditions of a lake. Therefore, the presence of Ceratopteris spores in sediments can be a valuable proxy of the depositional environment in lakes, bogs and other wetlands, and slow-moving rivers in a warm to hot, humid climate.

\subsection{Abundance of Pediastrum indicating changes in lake water levels}

Species of extant Pediastrum occur worldwide in still or slow-moving water bodies and typically occur in freshwater or slightly brackish lakes, ponds and river channels, especially in hard water [77]. Fossil occurrences are similarly world-wide. Those reported from marine sediments are usually attributable to transport by streams and rivers from non-marine environments into the marine realm, but they may also be present as a result of reworking of sediments during marine incursions.

Boudreau et al. [78] reported abundant specimens of $\mathrm{Pe}$ diastrum and other freshwater algae in the sediments of Lake Temagami in northeastern Ontario, Canada, and interpreted warm conditions associated with the Holocene Hypsithermal climate that prevailed in the study area during 6.25-4.115 ka BP (uncalibrated ${ }^{14} \mathrm{C}$ age) based on both pollen and algal data [78]. The palynomorph assemblage of Pediastrum, Carpinus, Corylus and Alnus in late interglacial deposits of the Baltic Sea, offshore Poland, indicates both a warm climate and a freshwater invasion into the marine realm [79]. A pollen analysis of Altiplano lake sediments in Bolivia consisting of interbedded lake muds and halite that accumulated during 90-21.5 cal ka BP reflects the alternating humid and arid conditions that are indicated by the sediments [80]. Remarkable fluctuations in the abundance of Pediastrum and the aquatic plant assemblage also indicate an arid environment dominated by salt deposition; however, humid conditions prevailed during 54-30.5 cal ka BP and the Last Glacial Maximum (LGM) and the period after that [80]. The freshwater algae Pediastrum, Zygnema and Spirogyra have been found in Holocene peat on the Rio Grande coastal plain, Brazil, indicating a lagoonal environment that was affected by marine transgressions and regressions [75]. In the Kerala Basin of western coastal India, an assemblage of Pediastrum and Botryococcus in Holocene sediments proved freshwater invasion and the development of lagoons [81]. In China, specimens of fossil and subfossil Pediastrum are commonly encountered in sediments from the very south of the country at Shuangchi Maar Lake on Hainan Island [42] and the continental shelf of the South China Sea [39] to the very north at Qian'an in Jilin [8] and Fula'erji in Heilongjiang [7]; from the bottom of the East China Sea [39] and the Yangtze Delta [6] to the alpine lakes 
of the Tibetan Plateau [33,34], Wulungu Lake in Xinjiang [36, 37], and lakes in the Tengger Desert of Inner Mongolia [29].

Abundances and water-depth relationships of occurrences of living Pediastrum in shallow freshwater or slightly salty lakes on the Tibetan Plateau and in western China have been investigated. Colonies of this alga have been found to increase with increasing depth of water. In Hurleg Lake in the Qaidam Basin (maximum water depth $8.6 \mathrm{~m}$ ), colonies gradually increased in number from depths of 0.6 $\mathrm{m}$ to $8 \mathrm{~m}$, but were absent below $8 \mathrm{~m}$ [31]. Numbers of colonies in bottom-surface sediment from Dianchi Lake in Yunnan (water depth $6.5 \mathrm{~m}$ ) dramatically increased from 2000 colonies $\mathrm{g}^{-1}$ (gram of dried sediment) at a depth of 4.5 $\mathrm{m}$ to 10000 colonies/g at $6.4 \mathrm{~m}$ [41]. Chen et al. [38] did not find any, or encountered only a very few, Pediastrum colonies in shallow-water sediments of Bosten Lake in Xinjiang, whereas concentrations of this alga gradually increased with depth down to $10 \mathrm{~m}$. For lakes that are less than $15 \mathrm{~m}$ deep [2], there seems to be a clear relationship between abundances in bottom-surface sediments and depth of water, which in turn can indicate changes in water level. Whether such a relationship is also apparent in deep lakes has yet to be investigated. In alpine lakes 20-90 m deep (e.g. Gongzhu Co, Mapeng Co, Beng Co, Mapangyon Co, Bangong Co), Pediastrum is commonly found in bottom-surface sediments. At least three species of Pediastrum have been found in such sediments in Nam Co and Pumoyon Co, which are more than 90 and $60 \mathrm{~m}$ deep respectively (Figures 5-7).

According to palynological records from PleistoceneHolocene lake sediments of the Tibetan Plateau, quite a few specimens of Pediastrum have been encountered, with especially high flux (colonies $\mathrm{cm}^{-2} \mathrm{a}^{-1}$ : yearly abundance and accumulation rate per unit area) in the middle-late Holocene deposits [69]. Pediastrum flux during 8.5-6.0 cal ka BP in Ren Co and Ahung Co reached 300-2000 colonies $\mathrm{cm}^{-2} \mathrm{a}^{-1}$, and between 10.8-9.0 and 2.0-1.5 cal ka BP in Hidden Lake it reached 500-700 colonies $\mathrm{cm}^{-2} \mathrm{a}^{-1}$. In Tglsh Co Pediastrum peak values of $300-400$ colonies $\mathrm{cm}^{-2} \mathrm{a}^{-1}$ occurred after 4.2 cal ka BP [33,82], and flux peaks of 2000-2500 colonies $\mathrm{cm}^{-2} \mathrm{a}^{-1}$ in Nam Co took place between 10.96-12.71 and 17.8 cal ka BP, respectively. In Hurleg Lake, Qaidam Basin, Pediastrum gradually increased to $76 \%$ of the palynomorph assemblage after $5.5 \mathrm{cal}$ ka BP (Figure 8) [31] and in Wulungu Lake, Xinjiang, it reached $43.4 \%$ during 5.21-3.62 cal ka BP and $15.6 \%-$ $43.3 \%$ between 9.55 and 7.74 cal ka BP [36,37]. In Shuangchi Maar Lake on Hainan Island and Huguangyan Maar Lake in Guangdong it reached 2000-6000 colonies $\mathrm{g}^{-1}$ during 1.7-2.4 and $4.5 \mathrm{cal} \mathrm{ka} \mathrm{BP}$, respectively [42,43].

Pediastrum influx values in Tglsh Co and Ahung Co reached peak values of 60 colonies $\mathrm{cm}^{-2} \mathrm{a}^{-1}$ during 4.5-3.0 cal ka BP and 400 colonies $\mathrm{cm}^{-2} \mathrm{a}^{-1}$ during 7.8-6.5 cal ka BP, respectively (Figure 8 ). These coincide with the highest total pollen influx values, the Po/Ar (Poaceae/Artemisia) ratio and the highest percentage of Cyperaceae pollen $[33,34]$. The increasing pollen influx values suggest that monsoon rainfall in the vicinity of the lakes also increased at that time. However, there is no evidence of a change in the composition of the vegetation and carbonate $\delta^{18} \mathrm{O}$ values remain very low. This suggests that the lakes overflowed in

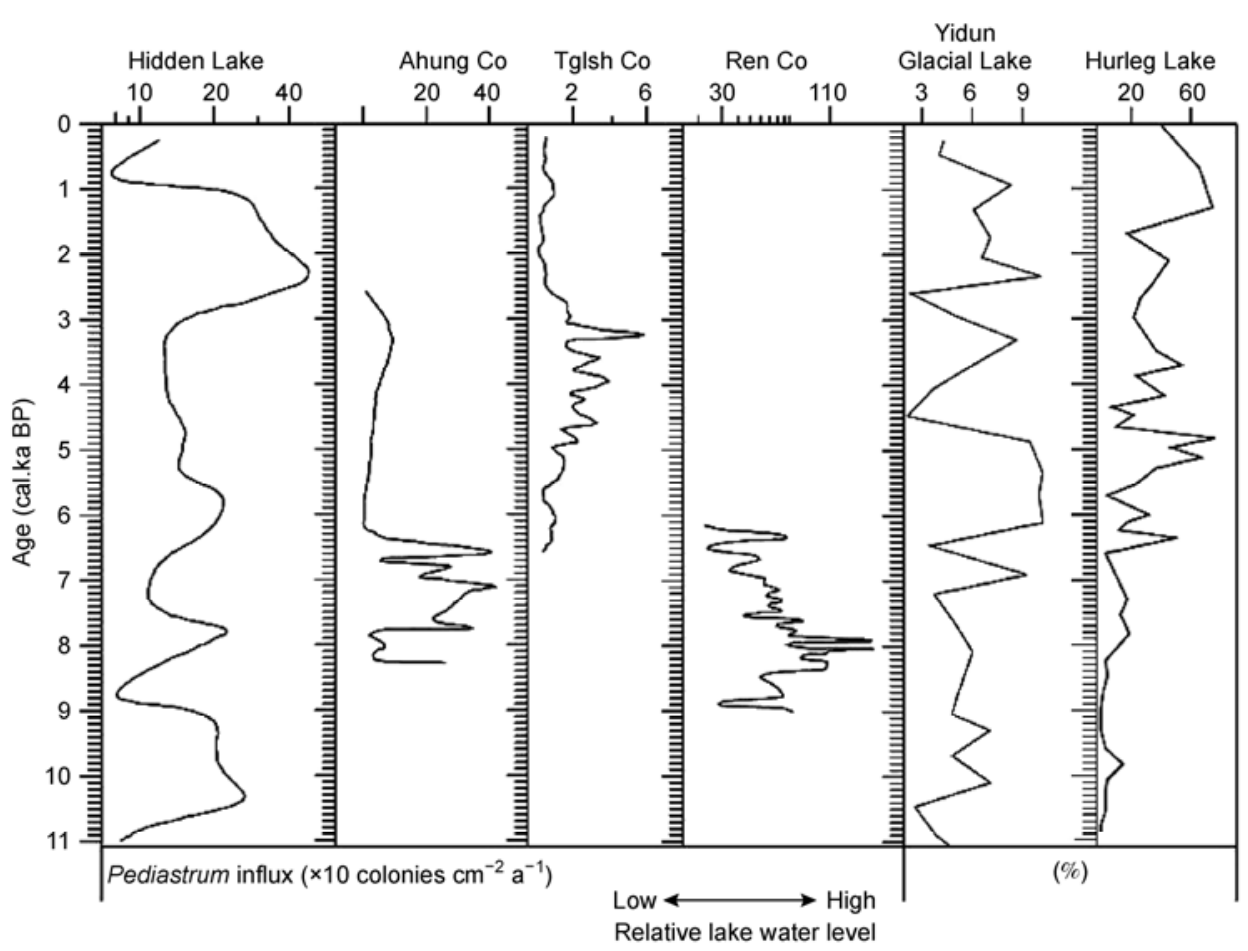

Figure 8 Pediastrum influx values (colonies $\mathrm{cm}^{-2} \mathrm{a}^{-1}$ ) in Holocene sediments of alpine lakes, Tibet [31]. 
response to the higher rainfall [33]. In other lake sediments, increasing numbers of Pediastrum colonies also imply higher monsoon rainfall. Numbers of Pediastrum colonies in Shuangchi Maar Lake on Hainan Island dramatically increased during 2.4-1.8 cal ka BP. This was 5-8 times more than during the period 1.7-1.3 cal ka BP and is interpreted to reflect enhanced monsoon rainfall and an enlarged lake area [42]. In arid northwest China, numbers of $P$. boryanum in drill core CK2022 in Qarhan Saline Lake reached 14.8\% during 31.8-25.6 ka BP, indicating that the lake water was fresher during this period than it had been previously [12]. In the Yimin Basin, Inner Mongolia Autonomous Region, the occurrence of $P$. boryanum in sediments dated to $4.5 \mathrm{ka}$ $\mathrm{BP}$ showed that moisture levels were higher at that time than previously [9]. In the Duantouliang sedimentary succession in the Tengger Desert, Pediastrum averages 31.5\% of the palynomorph assemblage between 28 and $30 \mathrm{cal}$ ka BP. This suggests that increased rainfall led to the formation of a lake in the desert [29].

Similar observations have been reported from other countries. In the State of Victoria, Australia, Pediastrum reached $81.7 \%$ of the palynomorph assemblage in Kelabit Crater Lake during 6.5-5.0 cal ka BP, indicating a humid climate and freshening of previously more saline conditions [73]. In Holocene deposits of Bollinger So, Denmark, the concentration of eight species of Pediastrum increased to 20000 colonies $\mathrm{cm}^{-2} \mathrm{a}^{-1}$, indicating a rise in alkaline water level [83].

In common with relative abundances of Pediastrum, changes in the abundance of Cyperaceae pollen in a palynomorph assemblage can be an indicator of varying lake levels in the alpine meadow-steppe ecotone on the central Tibetan Plateau. For a small lake like Xuguo Co, most Cyperaceae pollen comes from the swamp meadows that surround it. If the lake area becomes smaller these meadows may be enlarged, with the result that more Cyperaceae pollen is produced and deposited locally. In sediments younger than $8.5 \mathrm{cal} \mathrm{ka} \mathrm{BP}$, no specimens of Pediastrum have been recorded whereas the Cyperaceae pollen content gradually increases. This suggests that the lake water was fresh prior to $8.5 \mathrm{cal} \mathrm{ka}$ BP but as water levels lowered and the lake became smaller, conditions for the growth of Pediastrum were no longer suitable, although the presence of Cyperaceae pollen indicates that the water was still fresh $[33,34]$.

\subsection{Spiniferites indicating offshore, foreshore or marine-transgressive conditions}

As reported previously in numerous publications [e.g. 84] Spiniferites is typical of marine palynomorph assemblages and commonly dominates those recovered from sediments that accumulated in the open sea. A few examples follow. The brackish to brackish-marine species Spiniferites puyangensis He, Zhu and Jin has been encountered in early Oligocene sediments of coastal areas of Bohai and S. hexatypicus Matsuoka, S. pseudofurcatus (Klumpp) Sarjeant and S. ramosus were found in Miocene sediments of Niigata, Japan and the Qiongdong Basin on the northern continental shelf of the South China Sea [14]. There are continuous fossil records of Spiniferites from the Oligocene to the Early Pleistocene in the Bay of Biscay in the North Atlantic Ocean, and in Italy and Niigata, Japan: commonly recorded in abundance are S. membranaceus and S. ramosus. During the Pleistocene, species of S. mirabilis (Rossignol) Sarjeant and S. frigidus Harland and Reid were dominant in the North Pacific and North Atlantic oceans. In common with Pleistocene sediments in the Bering Sea, the northern North Pacific and the Rockall Plateau, Holocene deposits have also yielded numerous specimens of $S$. elongatus Reid, $S$. membranaceus, S. mirabilis and S. ramosus [70,85]. De Vernal and Mudie [86] linked Spiniferites-dominated assemblages with marine interglacial sediments; however, Edwards et al. [87] found it difficult to relate assemblages of this taxon to sea temperature and depth.

Our records of Holocene Spiniferites from Lüsi in Jiangsu, Hemudu and Linshan in Zhejiang, and Guangfulin, Fengxian and Chongming Island in Shanghai indicate offshore or near-shore/foreshore sedimentary environments in marine successions. The Pleistocene deposits at Taizhou and Xinghua in Jiangsu mainly reflect deposition in fresh water, but a few horizons have yielded Spiniferites, which must reflect occasional marine incursions.

\subsection{Abundant Concentricystes in lacustrine sediments commonly indicating a warm, humid climate}

Concentricystes is an alga that appears to have been able to adapt to a diverse range of freshwater habitats. It is widely distributed in Quaternary strata in China and elsewhere, mostly in lacustrine sediments and peats. Wall reported it to occur frequently in deep marine deposits and on the continental shelf [88]. However, there are no such anomalous records in China.

Abundant specimens of Concentricystes occur in Holocene peat and black lacustrine silts in eastern coastal areas of China in association with representatives of aquatic plants referable to the Cyperaceae, Typha, Potamogeton, Alisma and Lemna, and with species of other freshwater algae including Pediastrum, Zygnema and Cosmarium. The pollen assemblages in these areas reflect evergreen Quercus-dominated vegetation, and are indicative of a warm, humid climate in which freshwater lakes or alluvial flats with back-swamps prevailed [5]. Concentricystes has also been found in early Miocene deposits of the Longin Formation in the continental-shelf basin of the East China Sea, the Shidi Formation in Taiwan and the Ainoura Formation in Japan. It has often been found together with the pollen Sporotrapoidites and Rutaceoipollis and spores referable to Magnastriatites in Miocene lacustrine sediments in eastern China and Taiwan, here indicating a humid, warm temperate-subtropical climate $[47,89]$. It has also been reported from Pleistocene sediments in the southernmost of the 


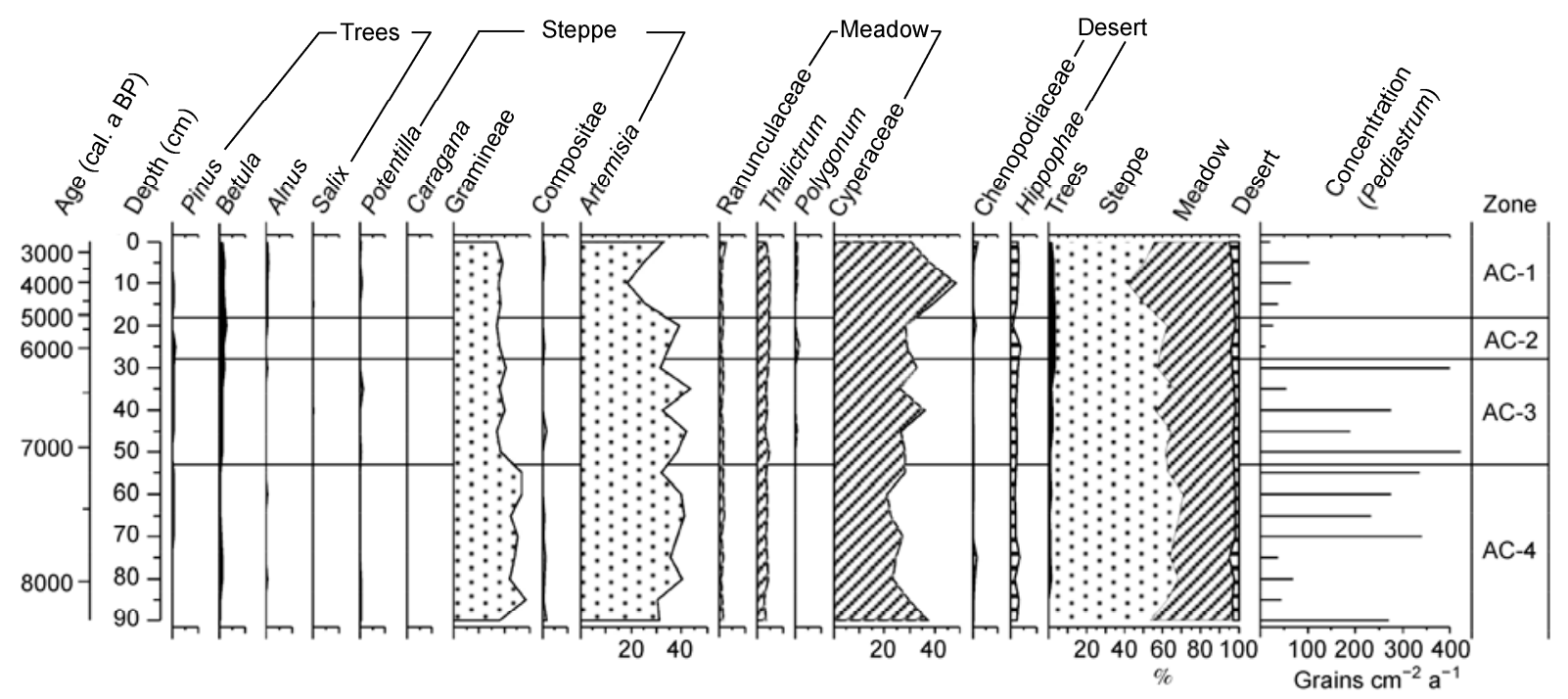

Figure 9 An example of numerical calculation: percentages of the main pollen and spore taxa and concentration of Pediastrum from Ahung Co, Tibet [33].

Nansha Islands in the South China Sea.

The relative abundance of Concentricystes shows a consistent increase in association with an increase in the variety of pollen types derived from tropical lowland rainforest on the Sunda Shelf since the last deglaciation. This may be linked to the onset of a rise in sea level [57]. In coastal Pleistocene sediments of the Beibu Gulf, China, it shows similar increasing trends associated with a greater variety of tropical and subtropical pollen representatives of such families as Lauraceae, Moraceae, Proteaceae and Sapindaceae, indicating a humid subtropical to tropical climate [5].

That Concentricystes has a wide tolerance of different climates is apparent from palynological records from the south to the north of China in Pleistocene-Holocene deposits. It has been recovered from Quaternary sediments on the Yellow Sea coast and in Helongjiang, North China, and from the Quaternary loess plateau of western China. Hence, regardless of whether conditions favoured a forest dominated by broadleaf trees in a warm, humid climate or a coniferous forest in a cold, relatively dry climate, fossil-subfossil Concentricystes occurs abundantly in lacustrine and other freshwater deposits, enabling the history of freshwater lake and associated environmental conditions to be determined.

\subsection{Estimation of concentrations of algae in palynolog- ical preparations}

Algae such as Pediastrum, Zygnema and Concentricystes are frequently identified and counted in Quaternary pollen analyses and can be helpful in determining conditions of deposition. Their occurrences should be recorded separately from those of pollen and spores. If percentages or concentrations of algae are included in total palynomorph counts, they reduce the amount of spore and pollen data upon which environmental conclusions pertaining to terrestrial vegeta- tion are based. Indeed, some of the observations on occurrences noted in this paper have relied on relative percentages of algae of this sort and not on separate counts, which we prefer. If algal concentrations are calculated independently, then algal flux (colonies $\mathrm{cm}^{-2} \mathrm{a}^{-1}$ or grains $\mathrm{cm}^{-2} \mathrm{a}^{-1}$ ) can be estimated (Figure 9), thus improving palaeoecological conclusions and palaeoenvironmental determinations.

This work was supported by the National Natural Science Foundation of China (40971029, 41072251 and 41171162), Knowledge Innovation Project of the Chinese Academy of Sciences (KZCX2-YW-155) and the Open Foundation of State Key Laboratory of Palaeobiology and Stratigraphy (113106). We thank Dr. Zhang Yun, Institute of Botany (CAS) for revision, Dr. Li Chunhai, Nanjing Institute of Geography and Limnology (CAS) for assistance in the preparation of ${ }^{14} \mathrm{C}$ data, and He Cuiling, Nanjing Institute of Geology and Palaeontology (CAS) for palynological processing of sediment samples. Special thanks are extended to two anonymous reviewers and the guest editor for their valuable comments, which helped to improve the manuscript.

1 Kong Z C, Du N Q, Wu Y S, et al. Discussion on the evolution of the natural environment around the Zhoukoudian Homo erectus pekinensis' living period based on pollen analysis (in Chinese). Chin Sci Bull (Chin Ver), 1981, 26: 1065-1067

2 Zhu H R, Zeng Z Q, Zhang Z Y. Fossil Pediastrum algae from the Dainan Formation (lower Tertiary) of northern Jiangsu with a note on their sedimentary conditions (in Chinese). Acta Palaeontol Sin, 1978, 17: 233-243

3 Wang K F, Zhang Y L. Climatic change in the Shanghai-Hangzhou area since $10 \mathrm{ka}$ based on pollen analysis (in Chinese). Hist Geog, 1981, 1: 126-131

4 Wang K F, Zhang Y L, Jiang H, et al. Pediastrum assemblages from late Pleistocene peat layers on the seafloor of the East China Sea and sea-level change (in Chinese). Chin Sci Bull (Chin Ver), 1981, 26: 109-112

5 Wang K F, Han X B. Study on the Cenozoic fossil Concentricystes in East China (in Chinese). Acta Palaeontol Sin, 1983, 22: 468-473

6 Mao L M, Wang W M, Shu J W, et al. Holocene spores and microscopic algae from the Yangtze Delta, East China (in Chinese). Acta Palaeontol Sin, 2011, 50: 154-165

7 Liu M, Du N Q, Kong Z C. Palynological analysis of the late Cenozoic and its significance in Fula'erji, Heilongjiang (in Chinese). J In- 
tegr Plant Biol, 1990, 32: 307-316

8 Jia C H, Yu L, Du N Q, et al. Changes of vegetation and climate in Qian'an County, Jilin since the late Tertiary (in Chinese). Sci Geog Sin, 1988, 9: 274-282

9 Kong Z C, Du N Q. Sporo-pollen analysis of some archaeological sites and preliminary discussion on the past flora and climate of Nei-Monggol Zizhiqu (Inner Mongolia Autonomous Region) (in Chinese). Acta Phytoecol Sin, 1981, 5: 193-204

10 Kong Z C, Du N Q, Xu Q H, et al. Paleoclimate fluctuations reflected in the flora of the Holocene Megathermal in the northern part of China (in Chinese). In: Shi Y F, ed. The Climates and Environments of the Holocene Megathermal in China. Beijing: China Ocean Press, 1992. 48-65

11 Kong Z C, Du N Q. Preliminary study on Holocene vegetation for high-temperature times and climate in some areas of China (in Chinese). Mar Geol Quat Geol, 1990, 10: 99-102

12 Du N Q, Kong Z C. Palynoflora of the Qarhan Saline Lake and its significance in geography and botany-the sporopollen assemblages from the CK2022 drill core at Bieletan (in Chinese). J Integr Plant Biol, 1983, 25: 275-282

13 Du N Q, Kong Z C. A preliminary investigation of the vegetational and climatic changes since 11000 years in Qinghai Lake-An analysis based on palynology in core QH85-14C (in Chinese). J Integr Plant Biol, 1989, 31: 879-891

14 Zhang J, Kong Z, Du N. Reconstruct[ion of] history [of] vegetation and environmental changes, Late Pleistocene in Beijing. Open IGBP/ BHAC-LUCC Joint Inter-core Projects Symposium. Kyoto, Japan, November, 1996. 38-41

15 Institute of Botany, Chinese Academy of Sciences. Pteridophyte Spore Flora of China (in Chinese). Beijing: Science Press, 1976. 1-41

$16 \mathrm{Xu} \mathrm{Q} \mathrm{H,} \mathrm{Wu} \mathrm{C,} \mathrm{Wang} \mathrm{Z} \mathrm{H.} \mathrm{Approach} \mathrm{to} \mathrm{palaeo-environment} \mathrm{in} \mathrm{the}$ west coast of Bohai Bay since 25000 a.B.P. Acta Phytoecol Sin, 1993, 17: 20-32

17 Qu X Y, He H, Zhuang Y, et al. Research on Holocene environmental change of the Dalianhua section in the Dalian area (in Chinese). In: Zhang L S, ed. Research on the Past Life-supporting Environmental Change of China. Beijing: China Ocean Press, 1993. 214-217

18 Xu Q H, Chen S Y, Kong Z C, et al. Preliminary discussion of vegetation succession and climate change since the Holocene in the Baiyangdian Lake district (in Chinese). Acta Phytoecol Sin, 1988, 12: 143-151

19 Han Y S, Meng G L. Changes in palaeogeographical environment of the Qingdao coast during the past 20000 years (in Chinese). Oceanol Limnol Sin, 1986, 17: 196-206

20 Li W Y, Liang Y L. Vegetation and environment of the hypsithermal interval of the Holocene in the eastern Hebei Plain (in Chinese). J Integr Plant Biol, 1985, 27: 650-651

21 Lu H Y. The sporo-pollen assemblages in sediments in the southern Bohai Sea since the late Pleistocene and their palaeoenvironmental analysis (in Chinese). Adv Mar Sci, 1989, 7: 11-26

22 Guan X T, Tian X M, Sun X H. Spore and pollen assemblages and their significance in Tertiary Bohai (in Chinese). In: Palynological Society of China, ed. The First Academic Conference Papers, Selections of the Palynological Society of China (1979). Beijing: Science Press, 1982. 64-70

23 Wang Y J, Li S W. Palaeovegetation and palaeoclimate in the past 20,000 years in Jiaozhou Bay, Qingdao District (in Chinese). J Integr Plant Biol, 1983, 25: 385-392

24 Liang Y L, Wang X C, Kong Z C, et al. The application of step-by-step discrimination analysis in reconstructing past climate (in Chinese). Chin Sci Bull (Chin Ver), 1991, 22: 1731-1734

25 Kong Z C, Du N Q. Dramatic changes in vegetation and climate since the late Pleistocene in eastern China (in Chinese). In: Liang M S, Zhang J L, eds. Comparison Research on Onshore and Offshore Quaternary in China. Beijing: Science Press, 1991. 165-172

26 Li Z R, Xu J R, Meng Q L, et al. Pollen assemblage and its stratigraphic significance for the Mesozoic in the Yellow Sea Basin (in Chinese). Mar Geol (Special Issue), 1984, 1: 1-32

27 Zhang Y Y. Tertiary spores and pollen grains from the Leizhou Peninsula (in Chinese). Acta Palaeontol Sin, 1981, 20: 449-458
28 Hou Y T, Li Y P, Jin Q H. Tertiary Palaeontology Atlas of Continental Shelf in Northern Part of South China Sea (in Chinese). Guangzhou: Guangdong Science and Technology Press, 1981. 1-58

29 Ma Y Z, Zhang H C, Li J J, et al. On the evolution of the palynoflora and climatic environment during late Pleistocence in Tengger Desert (in Chinese). J Integr Plant Biol, 1998, 40: 871-879

30 Wan W H, Tang L Y, Zhang H C, et al. Pollen record reflects climate changes in eastern Qaidam Basin during 36-18 ka BP (in Chinese). Chin Quat Sci, 2008, 28: 112-121

31 Zhao Y, Yu Z C, Chen F H, et al. Holocene vegetation and climate history at Hurleg Lake in the Qaidam Basin, northwest China. Rev Palaeobot Palynol, 2007, 145: 275-288

32 Lü X M, Zhu L P, Nishimura M, et al. A high-resolution environmental change record since $19 \mathrm{cal} \mathrm{ka}$ BP in Pumoyum Co, southern Tibet. Chin Sci Bull, 2011, 56: 2931-2940

33 Tang L Y, Shen C M, Li C H, et al. Pollen-inferred vegetation and environmental changes in the central Tibetan Plateau since $8200 \mathrm{yr}$ BP. Sci China Ser D-Earth Sci, 2009, 52: 1104-1114

34 Shen C M, Liu K B, Morill C, et al. Meadow-steppe ecotone shift and major central-scale droughts during the mid-Holocene in the central Tibetan Plateau. Ecology, 2008, 89: 1079-1088

35 Herzschuh U, Katia W, Bernd W, et al. A general trend on the central Tibetan plateau throughout the Holocene recorded by the Lake Zigetang pollen spectra. Quat Int, 2006, 154-155: 113-121

36 Liu X Q, Herzschuh U, Shen J, et al. Holocene environmental and climatic changes inferred from Wulungu Lake in northern Xinjiang, China. Quat Res, 2008, 70: 412-425

37 Xiao X Y, Jiang Q F, Liu X Q, et al. High resolution sporopollen record and environmental change since the Holocene in Wulungu Lake, Xinjiang (in Chinese). Acta Micropalaeontol Sin, 2006, 23: 77-86

38 Chen F H, Huang X Z, Yang M L, et al. Westerly dominated Holocene climate model in arid Central Asia-Case study on Bosten Lake, Xinjiang (in Chinese). China Quat Sci, 2006, 26: 882-887

39 Zhang Y L, Zhang M B. Discovery of freshwater algae in marine sediments and palaeoenvironmental significance (in Chinese). Mar Sci Bull, 2002, 21: 36-40

40 Wang K F, Zhang Y L, Sun Y H. The spore-pollen and algae assemblages from the surface layer sediments of the Yangtze River Delta (in Chinese). Acta Geogr Sin, 1982, 37: 261-271

41 Sun X J, Wu Y S. Distribution and quantity of sporopollen and algae in surface sediments of Dianchi Lake, Yunnan (in Chinese). Mar Geol Quat Geol, 1987, 7: 81-92

42 Zheng Z, Wang J H, Wang B, et al. High-resolution records of Holocene from the Shuangchi Maar Lake in Hainan Island. Chin Sci Bull, 2003, 48, 497-502

$43 \mathrm{Lu} \mathrm{H} \mathrm{Y,} \mathrm{Liu} \mathrm{J} \mathrm{Q,} \mathrm{Chu} \mathrm{G} \mathrm{Q,} \mathrm{et} \mathrm{al.} \mathrm{A} \mathrm{study} \mathrm{of} \mathrm{pollen} \mathrm{and} \mathrm{environment}$ in the Huguangyan Maar Lake since the last glaciation (in Chinese). Acta Palaeontol Sin, 2003, 42: 284-291

44 Zhen Y H, Zhou S F, Liu X Q, et al. Neogene sporo-pollen grains from northern Jiangsu and South Yellow Sea Basin (in Chinese). Monogr Nanjing Inst Geol Palaeontol (CAS), 1981, 3: 29-90

45 Bohai Petroleum Company of Chinese Offshore Petroleum Corporation, Nanjing Institute of Geology and Palaeontology (CAS). Study on Late Cenozoic Palynology of Bohai (in Chinese). Nanjing: Nanjing University Press, 1989. 25-48

46 Petroleum Research Institute of Exploration, Development and Programming of Petrochemical Industry Ministry, Nanjing Institute of Geology and Palaeontology (CAS). The Paleogene Dinoflagellates and Acritarchs from the Coastal Region of Bohai (in Chinese). Beijing: Science Press, 1978. 1-90

47 Offshore Geology Integration Research Department, Ministry of Geology and Mineral Resources, Bohai Petroleum Company of Chinese Offshore Petroleum Corporation, Nanjing Institute of Geology and Palaeontology (CAS). Research on Cenozoic Palynology of the Longjing Structural Area in the Shelf Basin of the East China Sea Region (in Chinese). Hefei: Anhui Science and Technology Press, 1985. 1-209

48 Yu J X. Dinoflagellates (in Chinese). In: Research party of Marine Geology, Ministry of Geology and Mineral Resources, Institute of 
Geology Chinese Academy of Geological Sciences, ed. Cenozoic Palaeobiota of the Continental Shelf of the East China Sea (Donghai) (Micropalaeobotanical Volume). Beijing: Geological Publishing House, 1989. 112-159

49 Zhu Y H. Late Pleistocene marine dinoflagellate from Dongying Depression, Shandong (in Chinese). Acta Micropalaeontol Sin, 2004, 21: $174-182$

$50 \mathrm{Ke}$ M H. Discovery and significance of Concentricystes fossils on the loess plateau (in Chinese). J Xi' an Coll Geol, 1995, 17: 90-93

51 Song Z C, Wang K F. Sporo-pollen complex from the Quaternary littoral deposits in Nantung, Kiangsu (in Chinese). Acta Palaeontol Sin, 1961, 9: 234-252

52 Wang S L, Xu Q Z, Zheng T. Quaternary sporopollen assemblage and palaeoclimate of Ducum Jiangsu (in Chinese). J Lanzhou Univ (Nat Sci), 1988, 24: 92-99

53 Wang K F, Zhang Y L. Palynological assemblages from late Quaternary sediments of the Ningbo Plain in Zhejiang and their palaeogeography (in Chinese). Sci Geog Sin, 1985, 5: 145-152

54 Wang K F. Palynological analysis of peat-bogs of Siyao Lake, Mount Hsishan, Nanchang, Kiangsi Province (in Chinese). J Integr Plant Biol, 1974, 16: 83-93

55 Tang L Y, Li Q W. Late Pleistocene spore and pollen in Hongkong (in Chinese). In: Li Z M, Chen J H, He G X, eds. Paleontology and Stratigraphy in Hongkong (Volume 2). Beijing: Science Press, 1998. 184-191

$56 \mathrm{Wu} \mathrm{Z} \mathrm{J,} \mathrm{Yu} \mathrm{J} \mathrm{F.} \mathrm{An} \mathrm{investigation} \mathrm{of} \mathrm{pollen-spore} \mathrm{assemblage} \mathrm{in} \mathrm{the}$ peat bed of the Mid-Epi-Pleistocene in Houhai, Shenzhen (in Chinese). Nanhai Stud Mar Sci, 1987, 8: 95-102

57 Wang X M, Sun X J, Wang P X, et al. Palynology and algae records and their palaeoenvironmental significance on Sunda Shelf since the last deglaciation (in Chinese). Acta Palaeontol Sin, 2008, 47: 313-318

$58 \mathrm{Wu}$ Y S. Studies on the spore morphology of Selaginella sinensis and its ecological significance (in Chinese). J Integr Plant Biol, 1989, 31: 77-80

59 Zhang J H, Kong Z C. Significance on ecological indication of Selaginella sinensis in reconstructing past environment (in Chinese). Acta Bot Boreal-Occid Sin, 1999, 19: 530-537

60 Krutzsch W, Sporen- und Pollengruppen aus der Oberkreide und dem Tertiär Mitteleuropas und ihre stratigraphische Verteilung. Z Angew Geol, 1957, 3: 509-548

61 Müller H. Palynological investigations of Cretaceous sediments in northeastern Brazil. In: Van Hinte J E, ed. In: Proceedings of the Second West African Micropaleontological Colloquium, Ibadan, 1965. Brill, Leiden, 1966. 123-136

62 Drugg W S. Palynology of the Upper Moreno Formation (Late Cretaceous-Paleocene), Escarpado Canyon, California. Palaeontogr B, 1967, 120: 1-71

63 Germeraad J H, Hopping C A, Muller J. Palynology of Tertiary sediments from tropical areas. Rev Palaeobot Palynol, 1968, 6: 189348

64 Liu J L, Ye P Y. Studies on the Quaternary sporo-pollen assemblage from Shanghai and Zhejiang with reference to its stratigraphic and palaeoclimatic significance (in Chinese). Acta Palaeontol Sin, 1977, 16: $1-10$

65 Ching R C. Flora Republicae Popularis Sinicae (Volume 2). Beijing: Science Press, 1959. 1-406

66 Evitt W R. Occurrence of fresh-water algae Pediastrum in Cretaceous of marine sediments. Am J Sci, 1963, 261: 890-893

67 Batten D J, Lister J K. Evidence of freshwater dinoflagellates and other algae in the English Wealden (Early Cretaceous). Cretaceous Res, 1988, 9: 171-179

68 Zhang $\mathrm{H}$, Zheng $\mathrm{Z}$, Wang $\mathrm{J} \mathrm{H}$, et al. Climate changes for the last 2500 years a based on Pediastrum record from Hainan Island (in Chinese). Trop Geog, 2004, 24: 109-112
69 Zamaloa M C, Tell G. The fossil record of freshwater micro-algae Pediastrum Meyen (Chlorophyceae) in southern America. J Paleolimn, 2005, 34: 433-444

70 Bujak J P. Cenozoic dinoflagellate cysts and acritarchs from the Bering Sea and northern North Pacific, DSDP Leg 19. Micropaleontology, 1984, 30: 180-212

71 Rossignol M. Hystrichosphères du Quaternaire en Méditerranée orientale, dans les sédiments pléistocènes et les boues marines actuelles. Rev Micropaléont., 1964, 7: 83-99

72 Wolff V H. Mikrofossilien des pliocanen Humodils der Grube Freigericht bei Dettingen a. M. und Vergleicht mit alteren Schichten der Tertiar sowie posttertiaren. Ablangerungen. Inst Paläobot Petrogr Brennsteine, Arbeit., 1934, 5: 55-101

73 Downie C, Williams G L, Sarjeant W A S. Classification of fossil microplankton. Nature, 1961, 192: 471

74 Rossignol M. Analyse pollinique de sediments marins quaternaires en Israel. 11. Sediments Pleistocènes Pollen Spores, 1962, 4: 121-148

75 Medeanic S. Freshwater algal palynomorph records from Holocene deposits in the coastal plain of Rio Grande do Sul, Brazil. Rev Palaeobot Palynol, 2006, 141: 83-101

76 Kong Z C, Du N Q, Zhang Z B. Vegetational development and climatic changes in the last 10,000 years in Beijing (in Chinese). J Integr Plant Biol, 1982, 24: 172-181

77 Hu H J, Li R Y, Wei Y X, et al. Freshwater Algae in China (in Chinese). Shanghai: Shanghai Science and Technology Press, 1980. 246-327

78 Boudreau R, Galloway J, Patterson R, et al. A paleolimnological record of Holocene climate and environmental change in the Temagami region, northeastern Ontario. J Paleolimn, 2005, 33: 445-461

79 Head M J, Marit-Solveig S, Janczyk-Kopikowa Z, et al. Last Interglacial (Eemian) hydrographic conditions in the southeastern Baltic Sea, NE Europe, based on dinoflagellate cysts. Quat Int, 2005, 130: 3-30

80 Chepstow-Lusty A, Bush M B, Frogley M R, et al. Vegetation and climate change on the Bolivian Altiplano between 108000 and 18000 years ago. Quat Res, 2005, 63: 90-98

81 Limaye R B, Kumaran K P N, Nair K M, et al. Non-pollen palynomorphs as potential palaeoenvironmental indicators in the Late Quaternary sediments of the west coast of India. Curr Sci, 2007, 92: 1370-1382

82 Tang L Y, Shen C M, Liu K B, et al. Climatic changes in the southeastern Qinghai-Tibetan Plateau during the Last Glacial Maximum Pollen records from southeastern Tibet. Sci China Ser D-Earth Sci, 2004, 34: 436-442

83 Sarmaja-Korjonen K, Seppanen A, Bennike O. Pediastrum algae from the classic late glacial Bolling So site, Denmark: response of aquatic biota to climate change. Rev Palaeobot Palynol, 2006, 138: 95-107

84 Costa L I, Downie C. Cenozoic dinocyst stratigraphy of Sites 403 to 406 (Rockall Plateau), IPOD, Leg 48. In: Montadert L, Roberts D G, eds. Init Repts Deep Sea Drilling Project, 1979, 48: 513-529

85 Downie C, Hussain M A, Williams G L. Dinoflagellate cyst and acritarch associations in the Paleogene of southeast England. Geosci Man, 1971, 3: 29-35

86 De Vernal A, Mudie P J. Pliocene and Quaternary dinoflagellate cyst stratigraphy in the Labrador Sea: Paleoenvironmental implications. In: Head M J, Wrenn J H, eds. Neogene and Quaternary Dinoflagellate Cysts and Acritarchs. Amer Ass Stratigr Palynol Found, Dallas, 1992. 329-346

87 Edwards L E, Anderle V A S. Distribution of selected dinoflagellate cysts in modern sediments. In: Head M J, Wrenn J H, eds. Neogene and Quaternary Dinoflagellate Cysts and Aacritarchs. Amer Ass Stratigr Palynol Found, Dallas, 1992. 259-288

88 Wall D. Fossil microplankton in deep-sea core from the Caribbean Sea. Palaeontology, 1967, 10: 95-123

89 Huang T C. Miocene palynomorphs of Taiwan (VI). Miscellaneous spores and pollen grains. Taiwania, 1981, 26: 45-57

Open Access This article is distributed under the terms of the Creative Commons Attribution License which permits any use, distribution, and reproduction in any medium, provided the original author(s) and source are credited. 